Regional and Business Studies (2020) Vol 12 No 2, 33-46

Szent István University Kaposvár Campus, Faculty of Economic Science, Kaposvár doi: $10.33568 /$ rbs. 2518

\title{
The Effects of Diversity on AChiEving REDUCEd INEQUALITIES
}

\author{
Phyllis DirRLer \\ Szent István University Kaposvár Campus, H-7400 Kaposvár, Guba Sándor u. 40.
}

ABSTRACT

The Sustainable Development Goals (SDG) were introduced in 2015 by the United Nations and include 17 goals and 169 actions on how to achieve a more sustainable future. This research addresses the SDG 10, which focuses on the reduction of inequalities. By 2030 the goal is to achieve reduced income inequalities, opportunity inequalities and all other forms which might hinder equal chances. The United Nations has already introduced financial and economic measures on how to achieve equality. The aim of this review paper is to challenge the current approaches by emphasizing that too little attention is paid on the people themselves. The goal achievement will require working groups of diverse nationalities, backgrounds, tenures and values. This research presents why it is essential to include diversity research in the work and how this can influence group processes and outcomes, such as conflict, performance or group commitment.

Keywords: value-, ethnic-, information-, tenure diversity, reduced inequalities JEL code: O33, M41, M42

\section{INTRODUCTION}

\section{The Sustainable Development Goals}

The Sustainable Development Goals (SDGs) came into effect on 01.01.2016 and are followed by all members of the United Nations (Figure 1). They are built on the Millennium Development Goals which were the basis for the work on a more sustainable future until 2015. These goals already provided a framework and led to great development and progress. The Sustainable Development Goals shall now in return go beyond those goals by defining economic, social and environmental objectives. The underlying motivation of the SDGs is also called the 5 PI's and consists of the following dimensions: Within the dimension of people the overall goal is to end poverty, hunger and inequality and to provide a healthy environment for all. The protection of the planet and actions on climate change are covered within the Planet division. Within property and peace, the achievement will be to provide a prosperous and fulfilling life to all and to enable life in peaceful societies without any crime. Partnerships will enable the achievement of the goals based on global solidarity and participation of all. These principles are further characterized by 17 Sustainable Development Goals and 169 precise targets. 
These efforts will overcome current failures such as poverty, hunger, inequalities, the disregard of Human Rights or the climate change. The SDGs describe actions until 2030, the year when all goals will be achieved by all nations (General Assembly, 2015).

\section{Figure 1}

\section{Overview of the Sustainable Development Goals:}
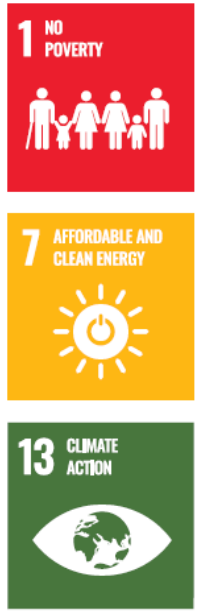
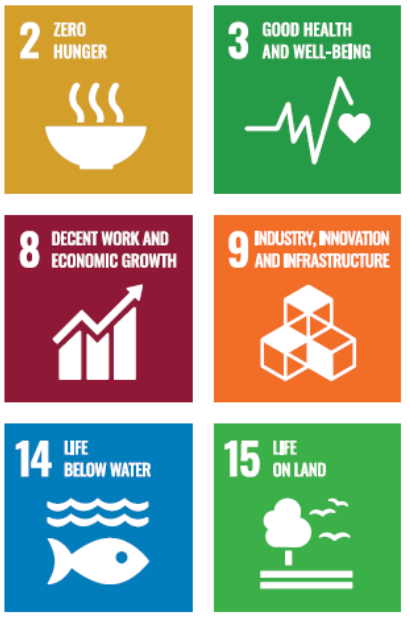
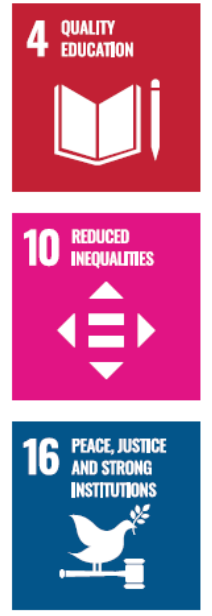
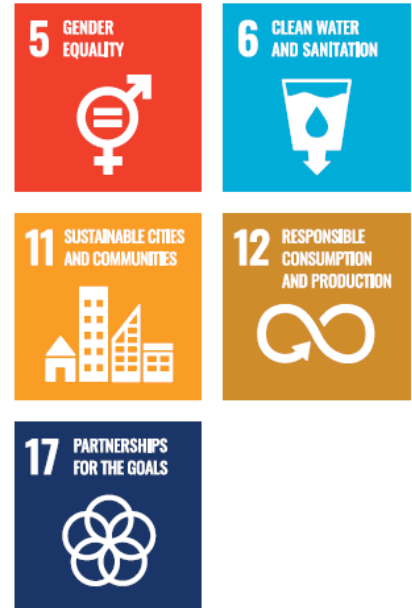

Source: United Nations Department of Global Communications, 2019

\section{Overview of the Sustainable Development Goals:}

All goals will be achieved by the countries individually, as well as on a global level, while ensuring that national policies and international laws are respected. However, it is considered that some countries require special attention and support. Governments, public institutions, international and regional institutions, academia, volunteer groups and all people are asked to work together closely. Global solidarity and joint approaches are essential, while still accepting that approaches, visions, models and tools vary among the countries (General Assembly, 2015). A variety of actions can be defined in order to ensure a goal achievement, which can among others be, the mobilization of financial resources, the transfer of technologies to favourable terms or financial sources. Further actions range from a more equally shared wealth to higher participations of less developed countries in international economic decision making (General Assembly, 2015). In the table below the working status and current achievements can be tracked per region and as data shows, there is still a significant amount of work to be done.

\section{Overview of the current level of goal achievement}

In general, the Sustainable Development Goals are highly interdependent and have significant relationships among many goals and targets, as for example that education reduces inequalities (Sachs et al., 2019)(Figure 2). Within this paper, however, the 
focus is mainly on Sustainable Development Goal 10, which is aimed at reducing inequalities within and among countries. According to the United Nations, inequality refers to 'the state of not being equal, especially in status, rights, and opportunities' (Afonso et al., 2015). Most often we refer to economic inequality which involves mainly the debate about two perspectives. First, this is the inequality of outcomes, associated with individuals not possessing the same amount of material wealth or general living economic conditions, such as standards of living, income, wealth, education, health and nutrition. Secondly, the debate involves inequality of opportunities, specifying the inequality of individuals not having the same opportunities to influence their life outcomes, such as attributes like gender, ethnicity, family background influencing their chances (Afonso et al., 2015). According to the United Nations, from 2011-2016 the bottom 40\% of the population managed to accomplish a higher income growth than the average, but income inequality stills rises in many parts of the world. Today the bottom $40 \%$ receive less than $25 \%$ of the total income or consumption, compared to the top $1 \%$, who receive an increasing share of income (United Nations, 2019).

\section{Figure 2}

\section{Overview of the current level of goal achievement}

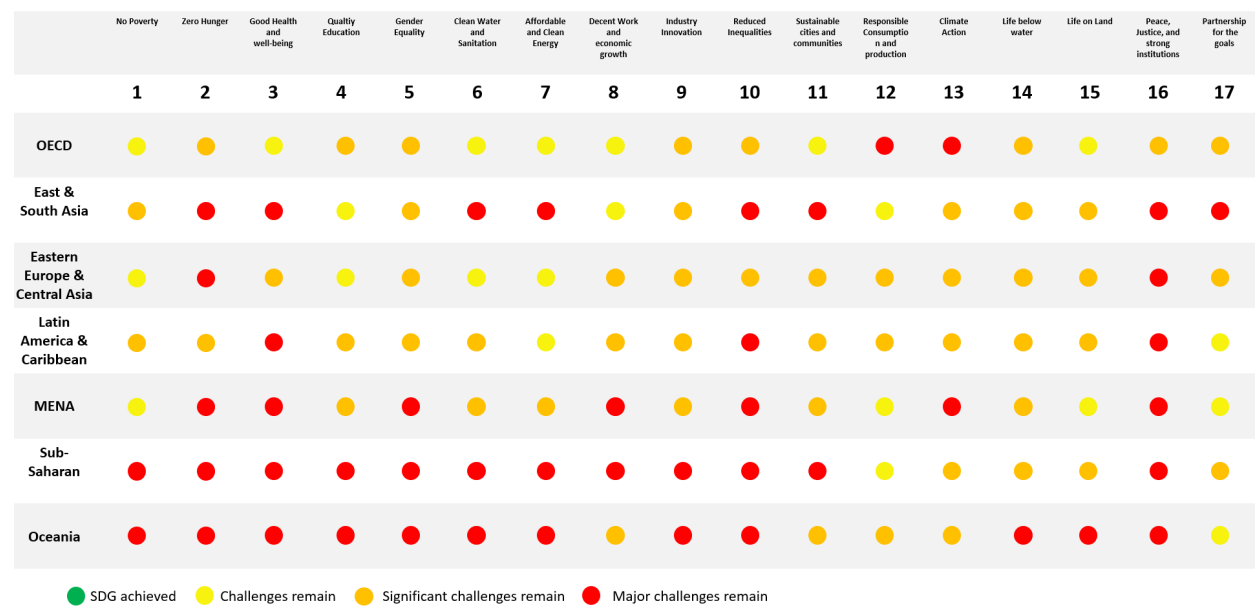

Source: Based on Sachs et al., 2019

Market forces are not sufficient to overcome the inequality gap, which leads to a rising demand of further actions (Sachs et al., 2019). These are among others the elimination of discriminatory laws, policies and practices. Furthermore, the United Nations suggests developing countries increase their representation in international organizations, economic and financial institutions use their voting shares and take part in decision-making. Further approaches can be summarized with Foreign Direct Investments in less developed countries, beneficial trade tariffs and duty free access 
for exports, which already takes place on large scales (Economic and Social Council, 2019).

Even though, actions are defined and worked on, the reduction of inequalities remains a major challenge for almost all countries, even in developed countries as shown above (Economic and Social Council, 2019). Despite all the introduced efforts and the emphasis of the United Nations to include economic, social and environmental factors, this paper suggests that additional research needs to be added. The argument is that current approaches focus too much on economic indicators, businesses and regulations, but too little on the people themselves. For a successful goal achievement cross-cultural, cross-functional and diverse working groups are required, as well as the regional population who need to adapt to these changes. I argue that even when reducing inequalities, inequalities or diversity matter significantly and need to be taken into account.

\section{METHODS}

To incorporate inequalities or diversity in the study and associate it with the SDGs, a narrative literature review was conducted. The data bases GoogleScholar, ScienceDirect and Ebsco were screened within the research to determine all relevant articles in the field of diversity research. In the first step, an overview is provided on the principles and effects of diversity according to current existing literature. In the second step, different diversity types are analysed based on the reactions, behaviour and consequences they have on individuals and groups. Whereas, these results also rest on current research findings of academia, in the final step a connection is established by the author, matching the literature status-quo on diversity with the author's suggestions of possible effects on the achievement of the SDGs. The suggested effects derive from the key results of the narrative literature review and provide recommendations for improvements, as well as further research.

\section{APPLICATION OF LITERATURE}

\section{Diversity Theory}

Diversity theory argues about a unique definition of diversity (Phillips \& O'Reilly, 1998), its causes, as well as its effects on group performance (Guzzo \& Dickson, 1996). Some researchers strengthen a narrow definition of diversity, only focusing on race, gender and cultural attributes (Cross et al., 1994), while others support larger definitions, including all possible variables (Thomas \& Ely, 1996). Within this work, I define diversity as any kind of attributes people use to differentiate themselves from another person (Mannix \& Neale, 2005; Phillips \& O'Reilly, 1998). Three major theoretical underpinnings characterize diversity research, which are social categorization, similarity attraction and the effects on information and decision making. Social categorization theory basically argues that differences in the demographic composition of work groups or teams 
influence group processes and performance (Phillips \& O'Reilly, 1998). It describes the assumption that individuals have a general desire to maintain high self-esteem, which is done via social comparison. Within this comparison individuals categorize themselves and others according to salient attributes, such as age, race, membership, status or religion (Tajfel, 1981; Turner et al., 1987). By doing so, individuals can define themselves regarding social identity, for example as an individual or a member of a group (Phillips \& O'Reilly, 1998). Individuals principally perceive themselves as positive, while tending to perceive others as less attractive (Kramer, 1991). This categorization is sufficient for individuals to regard outgroup members as less trustworthy, honest and cooperative compared to their favoured in-group members (Tajfel, 1982) and to apply stereotyping processes (Tajfel, 1981). Some research therefore suggests that heterogeneity in workgroups can generate decreased satisfaction, increased turnover desires, lower levels of cohesiveness, reduced communication and cooperation, as well as higher levels of conflict (e.g., Triandis et al., 1994). This already leads to the first argument, why diversity needs to be considered when reducing inequality. Working on a global level when achieving the Sustainable Development Goals involves people of a variety of demographic characteristics to work together, whereas social categorization can affect the processes and outcomes; according to theory most likely negatively. As social categorization is at least partly anchored to the subconscious level of everyone, it cannot be avoided or ignored by individuals. However, social categorization is contradicting to the goal which shall be achieved and might get people in difficult personal situations and decisions. Therefore, my first argument is to carefully study and discuss social categorization on a broader level that working teams can understand and resolve it accordingly.

Similarity attraction, the second theory influencing diversity research, suggests that individuals always prefer to work or interact with similar ones, when they have the choice to decide (e.g. Burt \& Reagans, 1997). Similarity can vary from attitudes and values, backgrounds to demographic variables, which in turn influence attraction and liking (Byrne et al., 1966), followed by work group processes and outcomes. The key negative outcomes suggested by research are decreased or incorrect communication as well as message distortion (Barnlund \& Harland, 1963), negative results on group processes and performance and a higher turnover rate (Jackson et al., 1993; Jehn et al., 1997). Resulting in the second argument, I suggest that working on the SDGs involves dissimilar partners to work on common goals. Most likely dissimilarity covers all areas such as values, backgrounds or demographic variables and therefore needs to be carefully addressed. My second argument is strongly related to the first one, which is to openly discuss similarity attraction and to agree on working modes and communication principles which enable group members to shape processes and outcomes as beneficially as possible.

Heterogeneity in work groups can also have positive outcomes, which leads to the third theory, the information and decision making. Research suggests that diverse teams might possess a broader range of skills, abilities, information and knowledge, which can in return positively affect decision-making (Tziner \& Eden, 1985). Most 
researchers therefore agree that multiple perspectives can be beneficial for a team, if problems are complex or tasks benefit from diverse inputs and if diversity is task-related, such as differences in skills or knowledge (Pelled et al., 1997). As already mentioned above, different institutions, governments, non-profit organizations and people are supposed to work on the SDGs. This work can benefit from the diverse skills and backgrounds the participants possess.

Next, I reflect on different types of diversity affecting the equality achievement and demonstrate which influences they have on an individual's affective reactions, their behavior and in the end, what kind of consequences this leads to, based on the model of Jackson and colleagues (Jackson et al., 2003)(Figure 3).

Researchers differentiate distinct categories of diversity, each consisting of different types of diversity. These categories are social-category differences, differences in knowledge or skills, differences in values or beliefs, Organizational or community-status differences and personality differences and differences in social and network ties (Mannix \& Neale, 2005). The latter two will not further be considered within this paper. For the remaining four categories, the most relevant diversity type according to its direct effect on the work of the United Nations was identified and is further discussed.

\section{Figure 3}

\section{Diversity types $\&$ its consequences}

\begin{tabular}{|c|c|c|c|c|}
\hline & Diversity & Reaction & Behavior & Consequence \\
\hline & - Value diversity & $\begin{array}{l}\text { - Decreases satisfaction } \\
\text { - Decreases commitment to remain }\end{array}$ & $\begin{array}{l}\text { - Increases relationship, task and } \\
\text { process conflict }\end{array}$ & $\begin{array}{l}\text { - Decreases work morale } \\
\text { - Decreases intent to remain } \\
\text { - Relationship decreases productivity, } \\
\text { information processing and } \\
\text { performance } \\
\text { - Mixed results on process and task } \\
\text { conflict and performance }\end{array}$ \\
\hline $\begin{array}{l}\infty \\
\stackrel{\infty}{g} \\
\frac{d}{3}\end{array}$ & - Information and Functional diversity & & $\begin{array}{l}\text { - Increases process and task conflict } \\
\text { - Increases communication } \\
\text { - Increases creativity }\end{array}$ & $\begin{array}{l}\text { - Increased performance when task are } \\
\text { complex } \\
\text { - Increases performance when social } \\
\text { category and value diversity are low }\end{array}$ \\
\hline 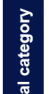 & - Ethnicity and race diversity & $\begin{array}{l}\text { - Lower satisfaction } \\
\text { - Lower commitment } \\
\text { - Lower social integration }\end{array}$ & $\begin{array}{l}\text { - Increases relationship, task and } \\
\text { process conflict } \\
\text { - Lowers openness } \\
\text { - Increases creativity }\end{array}$ & $\begin{array}{l}\text { - Minorities are more likely to leave } \\
\text { - Mixed results on performance } \\
\text { outcomes, possibly depending on the } \\
\text { emphasis of each conflict type }\end{array}$ \\
\hline 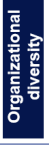 & - Tenure diversity & - Lower level of social integration & $\begin{array}{l}\text { - Poorer communication } \\
\text { - Increases relationship, task and } \\
\text { process conflict }\end{array}$ & $\begin{array}{l}\text { - Higher turnover rates } \\
\text { - Mixed performance results, possibly } \\
\text { depending on the emphasis of each } \\
\text { conflict type } \\
\text { - Lower degree of group functioning } \\
\text { - Problems during implementation } \\
\text { periods }\end{array}$ \\
\hline
\end{tabular}

Source: Based on Jackson et al., 2003

\section{Overview of diversity types and its reactions, behaviour and consequences}

\section{Value Diversity}

Value diversity describes any form of differences resulting from opposing opinions of group members about the real task, the actual goal and target or the mission of a group (Jehn et al., 1999). Jehn, Northcraft and Neale found out that perceived 
value diversity decreases work morale (Jehn et al., 1999), as well as satisfaction and commitment to the group (Mannix \& Neale, 2005). In regards to team behaviour research has proven that value diversity increases all types of conflict (Jehn et al., 1999). Even though, research is debating about a unified definition of conflict, within this paper I use the widely used definition of 'perceived incompatibilities or discrepant views among the parties involved' (Jehn \& Bendersky, 2003, p. 189). Most research differentiates between relationship, task and process conflict, whereas relationship and task conflict are most often referred to. Relationship conflict arises from interpersonal incompatibilities among group members (Jehn \& Bendersky, 2003) and comprises non-work related issues, such as personality differences or political beliefs (De Dreu \& Weingart, 2003; Jehn, 1995). Task conflict involves disagreements among group members about the task or ideas and opinions related to the task. It is linked to differences in viewpoints, ideas and opinions or disagreements about strategic decisions (De Dreu \& Weingart, 2003; Jehn, 1995). Process conflict entails means of how to accomplish a task, but doesn'tnot refer to questions about the task itself (Amason, 1996; Jehn, 1995). Some research argues that process conflict often contains an emotional component, comparable to relationship conflict, because it involves questions about desired resources or undesired assignments (Greer et al, 2005). The consequences of value diversity are on the one side hand a decreased intent to remain (Jehn et al., 1999) and on the other hand the consequences resulting from the increased conflict. Relationship conflict leads to decreased productivity, creativity and consensus (Wall \& Nolan, 1986) and negatively affects performance due to reduced abilities of members to process new information or new ideas and because of losses in time and energy (Pelled, 1996). Researchers present mixed results on the effects of task conflict. A majority of findings states that task conflict can have positive outcomes on team performance (Jehn et al., 1997; Jehn \& Mannix, 2001), due to improved decision makings or strategic planning via disagreements, increased information exchange and information assessment (Amason \& Schweiger, 1994; Jehn \& Bendersky, 2003), as well as enhanced creativity (DeDreu \& West, 2001; Nemeth, 1995; Nemeth, 2001). Some studies have, however, also proven proved that despite the positive outcomes, task conflict can cause dissatisfaction (Jehn, 1995) and negative affective reactions (Baron, 1990) and that people generally demonstrate higher level of satisfaction and an increased desire to stay within a group, when the group shows higher levels of consensus (Schweiger et al., 1986). Process conflict is complex, as it results out offrom tasks, but involves people, in forms of the assessment of individual abilities, skills or values (Jehn \& Bendersky, 2003). Discussions about resource allocation or task assignment in small amounts, especially when starting a task, can be beneficial (Jehn et al., 1997; Jehn \& Bendersky, 2003), but except of for that, most research results present negative results on performance (Jehn et al., 1999; Jehn \& Mannix, 2001; Thatcher et al., 1998).

It was has already been stated by the United Nations that the SDGs shall will be achieved, but that visions, tools and approaches can vary (General Assembly, 2015), which points out the existence of value diversity to some extent. As value diversity 
leads directly and indirectly to a variety of negative reactions, behaviours and performance outcomes, this needs to be considered and managed by the United Nations in order to avoid process or outcome losses.

\section{Informational and functional diversity}

Addressing differences in knowledge and skills, I focus next on information and functional diversity. Information and functional diversity are not clearly distinguished, but are interrelated, which results in me my considering them as one. Information diversity can be described as differences in knowledge and perspectives, which is most often caused by differences in education, experience or expertise (Jehn et al., 1999; Stasser, 1992). Jehn and colleagues have researched that information diversity increases process and task conflict, which resulted in increased performance outcomes, when value diversity and social category diversity were low (Jehn et al., 1999). Information diversity proved to be more beneficial for performance, when tasks were complex (Jehn et al., 1999), or involved high-quality decisions and creativity (Bunderson \& Sutcliffe, 2002; Carpenter, 2002). In general, functional and information diversity can have positive outcomes on group processes, whereas the negative effects of task and process conflict need to be considered, as well. Therefore, the Most most important one therefore is the management of conflict in order to foster the positive outcomes and avoid negative feelings and debates, which can hinder group processes and performance.

The SDG working groups and all people involved, will possess an incredible variety of backgrounds, education, and experiences. This diversity can benefit increase the group processes and performance significantly, if managed correctly. I therefore suggest that task and process conflict need to be carefully managed in order to enable all the people to achieve the best results.

\section{Ethnicity and race diversity}

Within the social category dimension, I will focus on ethnicity or race diversity, as this is the most visible diversity within the working groups to achieve equality among all people and nations. When referring to race, ethnicity or also cultural diversity, we most often refer to country-based diversity or cultures, but one can also differentiate between organizational or regional cultural differences (Stahl et al., 2010). Within this paper, I refer to diversity among countries. There is still little research on race and ethnicity diversity, compared to other variables such as functional or tenure diversity (Phillips \& O'Reilly, 1998). As already introduced earlier, social category diversity is expected to influence group processes and outcomes negatively (Jehn et al., 1999; Pelled et al., 1997), race and ethnicity being one of the most visible differences, is part of social categorization theory (Jehn et al., 2008). Some researchers argue that cultural diversity cause affective reactions, such as decreased satisfaction and commitment and increase all types of conflict, referring to process-, relationship-, and task conflict (Vodosek, 2005). Vodosek (2005) also stated within the research that in all three set-ups performance decreased. In addition to that, Research research suggests in addition 
that, that in the absence of priori group interactions, that the greater the cultural heterogeneity is, the more decreased the openness towards group members will be (Julian et al., 2009). However, other results found lower levels of social integration, but did not report any effects on relationship or process conflict or communication and satisfaction and even reported higher levels of creativity (Stabl et al., 2010). Phillips and colleagues also reported mixed results on performance outcomes, but stated that minorities were more likely to leave groups and to feel less satisfied (Phillips \& O'Reilly, 1998). It needs to be stated that several factors, such as national variety (Ayub \& Jehn, 2014), trust (Parayitam \& Dooley, 2007) or positive emotions (Shah \& Jehn, 1993) can influence group processes and outcomes, which might lead to different research results. Even though, diverse results exist, I argue that social categorization, and in more details, race and ethnicity influence the achievement of equality, as it might complicate the work itself. It is stated that the SDGs shall be achieved on a regional and global level and mainly with global solidarity. As the United Nations consists of almost all countries in the world, all races and ethnic groups will be represented and need to work on the reduction of inequalities. Even when having the goal to eliminate all forms of discriminatory laws and policies, this is not enough. Taking into account the findings of social categorization and the results of lower levels of satisfaction and openness and increased conflict, this diversity type needs to be openly discussed and managed by all working teams continuously.

\section{CONCLUSION}

The goal of this work is not to question the Sustainable Development Goals, or equality, because those initiatives are significant for a more sustainable and better future. The actions described by the United Nations are of great importance and shall be pursued without any hesitation. The purpose of my work is to strengthen the importance of putting the people themselves in the centre of discussion, because economic and financial measures will not be enough. Even though, it sounds ironic, that diversity matters, when reducing inequality, a great amount of research has already introduced how different types of diversity cause affective reactions, lead to unproductive behaviour, and harm group outcomes. A worldwide achievement of the Sustainable Development Goals demands work on a diverse level; possibly one of the most diverse works, which can exist. No matter how professional and experienced individuals are, diversity can still affect group processes and outcomes. This research has limitations and suggests further research, mainly on a precise evaluation of which diversity types affect the work on the SDG achievement most. Furthermore, I only point out the importance of considering diversity, with all forms of outcomes and do not give many suggestions. Future research should be added in order to provide suggestions on how to manage diversity correctly, in order to benefit of from it and try to avoid as many negative consequences as possible. Research has already provided some results on how training and commitment can benefit eliminate negative results (Kochan et al., 2003) and how trust can weaken the relationship between relationship and task conflict (Simons \& Peterson, 2000). 


\section{REFERENCES}

Alexander, J., Nuchols, B., Bloom, J., \& Lee, S. D. (1993). Organizational Demography and Turnover: An Examination of Multiform and Non-Linear Heterogeneity. https://escholarship.org/uc/item/1g50w5xm

Amason, A. C. (1996). Distinguishing the Effects of Functional and Dysfunctional Conflict on Strategic Decision Making: Resolving a Paradox for Top Management Teams. Academy of Management Journal, 39(1), 123-148. https://doi. org/10.2307/256633

Amason, A. C., \& Schweiger, D.M. (1994). Resolving the Paradox of Conflict, Strategic Decision Making, and Organizational Performance. International Journal of Conflict Management, 5(3), 239-253. https://doi.org/10.1108/ eb022745

Ancona, D., \& Caldwell, D. (1992). Demography and Design: Predictors of New Product Team Performance. Organization Science, 3(3), 321-341.

Ayub, N., \& Jehn, K. (2014). When diversity helps performance: Effects of diversity on conflict and performance in workgroups. International Journal of Conflict Management, 25(2), 189-212. https://doi.org/10.1108/IJCMA-04-2013-0023

Barnlund, D., \& Harland, C. (1963). Propinquity and Prestige as Determinants of Communication Networks. Sociometry, 26(4), 467-479. https://doi. org $/ 10.2307 / 2786149$

Baron, R. A. (1990). Countering the effects of destructive criticism: The relative efficacy of four interventions. Journal of Applied Psychology, 75(3), 235-245. https://doi.org/10.1037/0021-9010.75.3.235

Bunderson, J. S., \& Sutcliffe, K. (2002). Comparing Alternative Conceptualizations of Functional Diversity in Management Teams: Process and Performance Effects. The Academy of Management Journal, 45(5), 875-893. https://doi. org/10.2307/3069319

Burt, R., \& Reagans, R. (1997). Homophily, legitimacy, and competition: Bias in manager peer evaluations. Working Paper, Graduate School of Business, University of Chicago

Byrne, D., Clore, G. L., Jr., \& Worchel, P. (1966). Effect of economic similaritydissimilarity on interpersonal attraction. Journal of Personality and Social Psychology, 4(2), 220-224. https://doi.org/10.1037/h0023559

Carpenter, M. (2002). The Implications of Strategy and Social Context for the Relationship between Top Management Team Heterogeneity and Firm Performance. Strategic Management Journal, 23(3), 275-284.

Cross, E. Y., Katz, J. H., Miller, F. A., \& Seashore, E. W. (1994). The Promise of Diversity: Over 40 Voices Discuss Strategies for Eliminating Discrimination in Organizations. McGraw-Hill Companies

De Dreu, C. K. W., \& Weingart, L. R. (2003). Task versus relationship conflict, team performance, and team member satisfaction: A meta-analysis. Journal of Applied Psychology, 88(4), 741-749. https://doi.org/10.1037/0021-9010.88.4.741 
De Dreu, C. K. W., \& West, M. A. (2001). Minority dissent and team innovation: The importance of participation in decision making. Journal of Applied Psychology, 86(6), 1191-1201. https://doi.org/10.1037/0021-9010.86.6.1191

Greer, L. L., Jehn, K. A., \& Thatcher, S. M. B. (2005). Trust, conflict, and faultlines. $3^{\text {rd }}$ Workshop on Trust Within and Between Organisations, October 27-28, 2005. Amsterdam

Guzzo, R. A., \& Dickson, M. W. (1996). Teams in Organizations: Recent Research on Performance and Effectiveness. Annual Review of Psychology, 47(1), 307338. doi:10.1146/annurev.psych.47.1.307 https://doi.org/10.1146/annurev. psych.47.1.307

Hambrick, D., Cho, T., \& Chen, M. (1996). The Influence of Top Management Team Heterogeneity on Firms' Competitive Moves. Administrative Science Quarterly, 41(4), 659-684. https://doi.org/10.2307/2393871

Jackson, S. E., Stone, V. K., \& Alvarez, E. B. (1993). Socialization amidst diversity: Impact of demographics on work team oldtimers and newcomers. In Cummings, L. L., \& Staw B. M. (eds.) Research in organizational behavior. 15, 45-109. JAI Press, Greenwich, CT/London.

Jackson, S. E., Joshi, A., \& Erhardt, N. L. (2003). Recent Research on Team and Organizational Diversity: SWOT Analysis and Implications. Journal of Management, 29(6), 801-830. https://doi.org/10.1016/s0149-2063_03_00080-1

Jehn, K. A., \& Mannix, E. A. (2001). The dynamic nature of conflict: A longitudinal study of intragroup conflict and group performance. Academy of Management Journal, 44(2), 238-251. https://doi.org/10.2307/3069453

Jehn, K. A, Northcraft, G. B., \& Neale, M. A. (1997). Opening Pandora's box: A field study of diversity, conflict, and performance in work groups. Unpublished manuscript, Wharton School, University of Pennsylvania, Philadelphia

Jehn, K. A., Greer, L. L., \& Rupert, J. (n.d.). Diversity, conflict, and their consequences. Diversity at Work, 127-174. doi:10.1017/cbo9780511753725.007

Jehn, K., Greer, L. L., \& Rupert, J. (2008). Diversity, conflict, and their consequences. In Brief, A. (ed.) Diversity at Work. Cambridge Companions to Management, 127-174. Cambridge University Press, Cambridge, https://doi.org/10.1017/ cbo9780511753725.007

Jehn, K. A. (1995). A Multimethod Examination of the Benefits and Detriments of Intragroup Conflict. Administrative Science Quarterly, 40(2), 256-282. https:// doi.org/10.2307/2393638

Jehn, K.A., \&Bendersky, C. (2003). IntragroupConflict in Organizations: A contingency perspective on the conflict-outcome relationship. Research in Organizational Behavior, 25, 187-242. https://doi.org/10.1016/S0191-3085(03)25005-X

Jehn, K. A., Northcraft, G. B., \& Neale, M. A. (1999). Why differences make a difference: A field study of diversity, conflict, and performance in workgroups. Administrative Science Quarterly, 44(4), 741-763. https://doi. org/10.2307/2667054 
Julian, C. C., Wachter, R. M., \& Mueller, C. B. (2009). International Joint Venture Top Management Teams: Does Heterogeneity Make a Difference? Journal of AsiaPacific Business, 10(2), 107-129. https://doi.org/10.1080/10599230902880649 Kochan, T., Bezrukova, K., Ely, R., Jackson, S., Joshi, A., Jehn, K., Leonard, J., Levine, D., \& Thomas, D. (2003). The effects of diversity on business performance: Report of the diversity research network. Human Resource Management, 42(1), 3-21. https://doi.org/10.1002/hrm.10061

Kramer, R. (1991). Intergroup Relations and Organizational Dilemmas: The Role of Categorization Processes. Research in Organizational Behavior, 13, 191-228.

Mannix, E., \& Neale, M. A. (2005). What Differences Make a Difference?: The Promise and Reality of Diverse Teams in Organizations. Psychological Science in the Public Interest, 6(2), 31-55. https://doi.org/10.1111/j.15291006.2005.00022.x

Nemeth, C. J. (1995). Dissent as driving cognition, attitudes, and judgments. Social Cognition, 13(3), 273-291. https://doi.org/10.1521/soco.1995.13.3.273

Nemeth, C. J. (2001). The art of mentoring: it's personal. A tribute to Serge Moscovici. In Buschini, F., \& Kalampalikis, N. (eds.), Penser la vie, le social, la nature. Mélanges en l'honneur de Serge Moscovici. Paris, Editions de la Maison des sciences de l'homme.

O’Reilly, C. A., Caldwell, D. F., \& Barnett, W. P. (1989). Work Group Demography, Social Integration, and Turnover. Administrative Science Quarterly, 34(1), 21-37.

O'Reilly, C., Snyder, R., \& Boothe, J. (1993). Effects of executive team demography on organizational change. In G. Huber \& W. Glick (eds.), Organizational change and redesign, 147-175. Oxford University, New York

Parayitam, S., \& Dooley, R. S. (2007). The relationship between conflict and decision outcomes: Moderating effects of cognitive- and affect-based trust in strategic decision-making teams. International Journal of Conflict Management, 18(1), 42-73. https://doi.org/10.1108/10444060710759318

Pelled, L., Eisenhardt, K., \& Xin, K. (1997). Demographic diversity in work groups: An empirical assessment of linkages to intragroup conflict and performance. Working Paper, School of Business.

Pelled, L. (1996). Demographic Diversity, Conflict, and Work Group Outcomes: An Intervening Process Theory. Organization Science, 7(6), 615-631. http://www. jstor.org/stable/2635051

Phillips, K. W., \& O'Reilly, C. A. (1998). Demography and Diversity in Organizations: A Review of 40 Years of Research. Research in Organizational Behavior, 20, $77-140$.

Sachs, J., Schmidt-Traub, G., Kroll, C., Lafortune, G., \& Fuller, G. (2019). Sustainable Development Report 2019: Transformations to achieve the Sustainable Development Goals, Includes the SDG Index and Dashboards. Bertelsmann Stiftung and Sustainable Development Solutions Network (SDSN), New York, https://s3.amazonaws.com/sustainabledevelopment.report/2019/2019_ sustainable_development_report.pdf 
Schweiger, D., Sandberg, W., \& Ragan, J. (1986). Group Approaches for Improving Strategic Decision Making: A Comparative Analysis of Dialectical Inquiry, Devil's Advocacy, and Consensus. The Academy of Management Journal, 29(1), 51-71. https:/doi.org/10.2307/255859

Shah, P. P., Jehn, K. A. (1993). Do friends perform better than acquaintances? the interaction of friendship, conflict, and task. Group Decision Negotiation 2, 149-165 https://doi.org/10.1007/BF01884769

Simons, T. L., \& Peterson, R. S. (2000). Task conflict and relationship conflict in top management teams: The pivotal role of intragroup trust. Journal of Applied Psychology, 85(1), 102-111. https://doi.org/10.1037/0021-9010.85.1.102

Smith, K. G., Smith, K. A., Olian, J. D., Sims, H. P., O’Bannon, D. P., \& Scully, J. A. (1994). Top Management Team Demography and Process: The Role of Social Integration and Communication. Administrative Science Quarterly, 39(3), 412. https://doi.org/10.2307/2393297

Stahl, G. K., Maznevski, M. L., \& Jonson, K. (2010). Unraveling the effects of cultural diversity in teams: A meta-analysis of research on multicultural work groups. Journal of International Business Studies, 41(4), 690-709.

Stasser, G. (1992). Information salience and the discovery of hidden profiles by decision-making groups: A "thought experiment". Organizational Behavior and Human Decision Processes, 52(1), 156-181. https://doi.org/10.1016/07495978(92)90049-D

Tajfel, H. (1981). Human groups and social categories: Studies in social psychology. Cambridge University Press, Cambridge, England

Tajfel, H. (1982). Social identity and intergroup relations. Cambridge University Press, Cambridge, England

Thatcher, S. M. B., Jehn, K. A., \& Chadwick, C. (1998). Understanding the impact of differences: Individual demographic differences, group diversity, and conflict. Annual Meeting of the Academy of Management, San Diego, CA

Thomas, D. A., \& Ely, R. J. (1996). Making Differences Matter: A New Paradigm for Managing Diversity. Harvard Business Review, 74(5), 79-90.

Triandis, H., Kurowski, L., \& Gelfand, M. (1994). Workplace diversity. Consulting Psychologists Press, 4, 769-827.

Triandis, H. C., Kurowski, L. L., \& Gelfand, M. J. (1994). Workplace diversity. In Triandis, H. C., Dunnette, M. D., \& Hough, L. M. (eds.), Handbook of industrial and organizational psychology, 769-827, Consulting Psychologists Press.

Turner, J. C., Hogg, M. A., Oakes, P. J., Reicher, S. D., \& Wetherell, M. S. (1987). Rediscovering the social group: A self-categorization theory. Basil Blackwell.

Tziner, A., \& Eden, D. (1985). Effects of crew composition on crew performance: Does the whole equal the sum of its parts? Journal of Applied Psychology, 70(1), 85-93. https://doi.org/10.1037/0021-9010.70.1.85

United Nations Department of Economic and Social Affairs (2015). Concept of Inequality: Development Issues No. 1. https://www.un.org/en/development/ desa/policy/wess/wess_dev_issues/dsp_policy_01.pdf 
United Nations (2019). Report of the Secretary-General on SDG Progress 2019: Special Edition. https://sustainabledevelopment.un.org/content/documents/24978Report_ of_the_SG_on_SDG_Progress_2019.pdf

United Nations (2019). Special edition: progress towards the Sustainable Development Goals. https://undocs.org/E/2019/68

United Nations (2019). Sustainable Development Goals. https://www.un.org/sustainabledevelopment/wp-content/uploads/2019/01/SDG_Guidelines_AUG_2019_Final.pdf

United Nations (2015). Transforming our world: the 2030 Agenda for Sustainable Development. https://www.un.org/ga/search/view_doc.asp?symbol=A/RES/70/1\&Lang=E.

Vodosek, M. (2005). Cultural Diversity, Intragroup Conflict, and Group Outcomes: Evidence for a Mediated Relationship. Academy of Management Proceedings, 2005(1), D1-D6. https://doi.org/10.5465/ambpp.2005.18778533

Wall, V. D., \& Nolan, L. L. (1986). Perceptions of Inequity, Satisfaction, and Conflict in Task-Oriented Groups. Human Relations, 39(11), 1033-1051. https://doi. org/10.1177/001872678603901106

Corresponding author:

\section{Phyllis DirrLer}

Szent István University Kaposvár Campus

Doctoral School in Management and Organizational Sciences

H-7400 Kaposvár, Guba Sándor u. 40.

e-mail: phyllis.dirrler@yahoo.com

(C) Copyright 2020 by the authors.

This is an open access article under the terms and conditions of the

Creative Commons attribution (CC-BY-NC-ND) license 4.0.

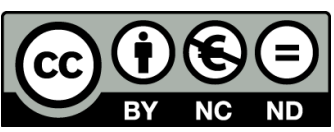

